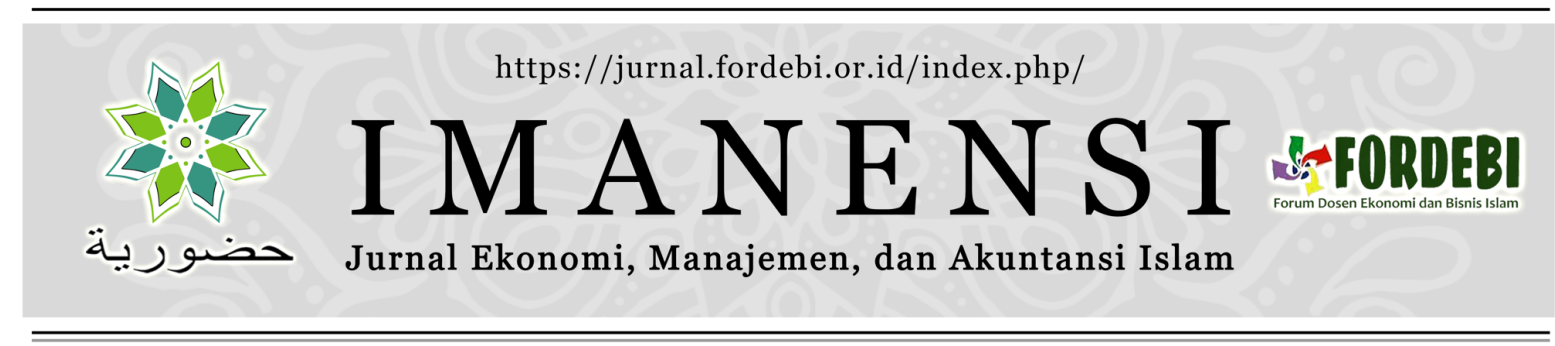

\title{
PENGEMBANGAN MODEL KURIKULUM EKONOMI AKUNTANSI BERBASIS SOSIAL, BUDAYA, DAN RELIGI ISLAM
}

\author{
Niswatin $a, 1$ *, La Ode Rasuli $b, 2$ \\ a,b Universitas Negeri Gorontalo, J Jenderal Sudirman no 6, Gorontalo, 96128, Indonesia. \\ 1niswatin@ung.ac.id*; 21a.rasuli@ung.ac.id \\ *Corresponding author
}

\section{INFO ARTIKEL \\ IMANENSI \\ Volume 6 \\ Nomor 1 \\ Halaman 43-54 \\ Malang, Maret 2021 \\ ISSN: 2339-1847 \\ e-ISSN: 2683-9968 \\ Kronologi Artikel: \\ Tanggal Masuk: \\ 1 Januari 2020 \\ Tanggal Revisi: \\ 3 Maret 2021 \\ Tanggal Diterima: \\ 15 Maret 2021}

Kata Kunci:

Kurikulum Ekonomi Syariah;

Model Monolitik;

Model Integratif;

Pembelajaran;

Keywords:

Integrative Model;

Islamic Economics Curriculum;

Learning;

Monolithic Model;

\section{(1) (2)}

Disitasi sebagai: Niswatin dan Rasuli, L.O. (2021). Pengembangan Model Kurikulum Ekonomi Akuntansi Berbasis Sosial, Budaya, Dan Religi Islam. IMANENSI: Jurnal Ekonomi, Manajemen, dan Akuntansi Islam, 6(1), 43-54. https://doi.org/10.34202/imanensi.6.1.2021.43-54.

\begin{abstract}
Abstrak: Pengembangan Model Kurikulum EkonomiAkuntansi Berbasis Sosial, Budaya, Dan Religi Islam. Penelitian ini dilakukan untuk menemukan model pengembangan kurikulum ekonomi syariah dan akuntansi di sekolah menengah tingkat atas sederajat. Observasi, dokumentasi, dan focus group discussion dipilih untuk mendapatkan data. Hasil penelitian menemukan dua model kurikulum, yaitu 1). model monolitik yang diterapkan di Sekolah Menengah Kejuruan (SMK) program studi Perbankan Syariah dengan adanya mata pelajaran ekonomi syariah dan akuntansi perbankan syariah dan di Madrasah Aliyah (MA) dengan mata pelajaran ekonomi syariah sebagai mata pelajaran peminatan dan muatan lokal, dan 2). Model integratif yang dapat diterapkan di Sekolah Menengah Atas (SMA).
\end{abstract}

\begin{abstract}
Development of an Islamic Social, Cultural and Religious Based Economic-Accounting Curriculum Model. The purpose of this study is to find a model for the development of Islamic economics and accounting curricula in senior secondary schools. Observations, documentation, and focus group discussions were selected to obtain data. The results of the study found two curriculum models, namely 1). the monolithic model applied in the Vocational High School of the Islamic Banking study program with the existence of Islamic economics and Islamic banking accounting subjects and in Madrasah Aliyah (MA) with Islamic economics as a subject of local interest and content, and 2). An integrative model that can be applied in Senior High Schools.
\end{abstract}

\section{PENDAhUluan}

Masyarakat Gorontalo dari aspek sosial, budaya, dan religi memiliki keunikan. Filosofi hidup "Adat bersendikan syara, syara bersendikan Kitabullah" yang dimilikinya menjadikan syariah (Islam) sebagai pedoman hidupnya. Dengan filosofi ini, sesungguhnya sangat potensial dalam mengembangkan ekonomi, bisnis, dan akuntansi syariah sebagai alternatif model dalam pembangunan daerah untuk meningkatkan kesejahteraan masyarakatnya (Niswatin et al., 2016).

Kendala yang dihadapi dalam pengembangan ekonomi syariah di Gorontalo di antaranya adalah masih rendahnya pengetahuan dan kesadaran masyarakatnya 
tentang ekonomi, bisnis, dan akuntansi Syariah (Niswatin dkk, 2016). Pendekatan mobilitas sosial dengan merevitalisasi fungsi lembaga pendidikan dalam program edukasi dan sosialisasi sejak dini tentang ekonomi, bisnis, dan akuntansi syariah melalui pengembangan kurikulum ekonomi syariah dan akuntansi syariah di SMA sederajat sangat diperlukan, hal ini sejalan dengan kurikulum dan pembelajaran berbasis kesejahteraan semesta yang mampu menjadikan manusia mengimplementasikan ilmunya untuk kesejahteraan umat manusia (Kamayanti \& Lutfillah, 2020).

Gorontalo yang mayoritas berpenduduk muslim memiliki sumber daya yang berpotensi dalam pengembangan kurikulum ekonomi dan akuntansi syariah, diantaranya adalah lembaga pendidikan (Niswatin dkk, 2017a). Lebih lanjut Niswatin dkk (2017b) menemukan faktor dominan pengembangan kurikulum ekonomi syariah dan akuntansi syariah di Gorontalo ditentukan oleh peningkatan pengetahuan bagi masyarakat dalam upaya meningkatkan kesadaran berekonomi, berbisnis, dan berakuntansi berdasarkan nilai-nilai Islam.

Faktor sosial budaya dan religi menjadi landasan yang sangat penting dalam penyusunan kurikulum yang relevan, karena kurikulum merupakan alat untuk merealisasikan sistem pendidikan, sebagai salah satu dimensi dari kebudayaan (Hamalik, 2009 dan Kunandar, 2011). Alotaibi et al., (2016) dan Triyuwono, (2015) menjelaskan bahwa pengembangan kurikulum ekonomi syariah (di dalamnya termasuk edukasi tentang perbankan syariah, keuangan syariah, dan akuntansi syariah) menjadi sebuah keharusan untuk mengantarkan peserta didik memiliki pemahaman dan kesadaran yang kuat dalam mengimplementasikan nilai-nilai Islam dalam kehidupan berekonomi, berbisnis, dan berakuntansi. Lebih lanjut Triyuwono, (2015) menjelaskan bahwa harapan pengembangan kurikulum tersebut diarahkan untuk mencetak peserta didik menjadi manusia yang bertakwa kepada Allah SWT dan pembentukan karakter yang jujur, adil, amanah, dan akuntabel dalam berekonomi, berbisnis, dan berakuntansi.

Menurut Yunus (2011), metode pembelajaran yang dikembangkan dalam kurikulum merupakan faktor yang memengaruhi ketercapaian hasil belajar dan mampu meningkatkan kesadaran peserta didik mengimplementasikan materi dalam kehidupannya. Oleh karena itu, penelitian ini sangat penting dilakukan untuk menemukan model pengembangan kurikulum ekonomi syariah dan akuntansi syariah di SMA sederajat. Upaya ini dilakukan untuk mewujudkan masyarakat yang sejahtera dan memiliki kesadaran nilai-nilai Ketuhanan dalam mengimplementasikan berbagai segi kehidupan.

\section{METODE}

Penelitian ini menggunakan pendekatan kualitatif dengan tehnik pengumpulan data observasi, dokumentasi, dan focus group discussion (FGD). Teknik observasi digunakan untuk mendapatkan data dan informasi tentang kurikulum ekonomi dan akuntansi di jenjang SMA/ sederajat. Observasi sekolah yang telah menerapkan kurikulum ekonomi syariah dan akuntansi syariah dilakukan di SMK yang berada di daerah Surabaya dan Malang Jawa Timur. Sedangkan observasi sekolah SMA dan MA dilakukan di daerah Gorontalo. Teknik dokumentasi digunakan dengan menganalisis kurikulum yang berlaku dan analisis Al-Quran serta data pendukung yang relevan.

Teknik FGD melibatkan dinas yang terkait, pakar bidang pengembangan kurikulum khususnya ekonomi dan akuntansi, guru pengajar ekonomi dan akuntansi, ulama, Ikatan Ahli Ekonomi Islam (IAEI) Wilayah Gorontalo, Masyarakat Ekonomi Syariah (MES), Asosiasi Guru Ekonomi Indonesia (AGEI) Wilayah Gorontalo, Forum Dosen Ekonomi dan Bisnis Islam (Fordebi) Wilayah Gorontalo, dan 
akademisi/peneliti. Untuk mendukung keabsahan data penelitian dilakukan melalui ketekunan dalam pengamatan dan kecukupan referensi yang tersedia. Teknik analisis data dilakukan dengan tahapan reduksi data, penyajian data, dan penarikan kesimpulan.

\section{HASIL DAN PEMBAHASAN}

Kurikulum merupakan salah satu variabel yang dapat memengaruhi sistim pendidikan. Kurikulum yang baik adalah kurikulum yang dapat mengikuti dinamika yang ada dalam masyarakat. Dalam pengertian ini, kurikulum harus mampu menjawab kebutuhan masyarakat luas dalam menyelesaikan persoalan-persoalan kehidupannya.

\subsection{Dimensi Sosial Budaya, dan Religi dalam pengembangan Kurikulum Ekonomi Akuntansi di SMA sederajat}

Penjelasan mengenai perlunya mempertimbangkan aspek sosial budaya dan religi dalam pengembangan kurikulum ekonomi-akuntansi di jenjang SMA sederajat di Gorontalo disampaikan oleh Heldy Vanni Alam. Berikut pokok pikirannya yang disampaikan pada FGD:

"Agama merupakan sesuatu yang harus diyakini keberadaan dan kebenarannya, khususnya bagi kita umat Islam. Mengingat Gorontalo merupakan daerah mayoritas penduduknya beragama Islam, sehingga perlu kearifan lokal, khususnya pembelajaran ekonomi dan akuntansi syariah di SMA sederajat dijadikan sebagai materi khusus dalam konteks pengenalan dan pembiasaan. Hal ini didukung pula oleh landasan filosofi masyarakat Gorontalo yang menyandarkan aktivitas adat dan budayanya kepada kitabullah (Al-quran)" (Heldy Vanni Alam, akademisi di Fakultas Ekonomi Universitas Negeri Gorontalo dan sebagai Pengurus Forum Dosen Ekonomi dan Bisnis Islam Wilayah Gorontalo).

Hal ini didukung pula oleh Rio Monoarfa, Andi Yusniar Mendo, dan Sofhian. Sebagaimana pernyataan mereka yang disampaikan pada FGD di bawah ini:

"Diperlukan penguatan ekonomi dan akuntansi syariah pada kurikulum di SMA sederajat sebagai penguat karakter yang sesuai dengan jati diri budaya Gorontalo "adat bersendikan syara, syara bersendikan kitabullah". Pijakan dan dasar hukum terhadap pengembangan kurikulum SMA untuk memasukan muatan lokal terutama ekonomi dan akuntansi syariah." (Rio Monoarfa, akademisi di Jurusan Akuntansi Fakultas Ekonomi Universitas Negeri Gorontalo).

"Pengembangkan kurikulum ekonomi syariah dan akuntansi syariah di SMA/Sederajat sangat penting dikarenakan masyarakat Indonesia mayoritas Islam dimana ekonomi syariah sangat fleksibel". (Andi Yusniar Mendo, Pengurus Ikatan Sarjana Ekonomi Indonesia (ISEI) wilayah Gorontalo).

"Wajib untuk dikembangkan, namun pada kurikulum dasar. Kementerian terkait harus merumuskan kurikulum seragam". (Sofhian, Dosen di Institut Agama Islam Negeri Sultan Amai dan sebagai Ketua Ikatan Ahli Ekonomi Islam (IAEI) Wilayah Gorontalo. 
Pernyataan-pernyataan informan menunjukkan bahwa kondisi sosial, budaya, dan religi suatu masyarakat menjadi bagian yang terpenting untuk dipertimbangkan dalam melakukan pengembangan kurikulum yang sedang diterapkan. Pengembangan kurikulum ini didasarkan pada pandangan bahwa pembelajaran sebagai proses dari pendidikan berakar pada budaya masyarakat untuk membangun kehidupan bangsa masa kini dan yang akan datang. Harapan-harapan yang ingin dituju dari pengembangan kurikulum ekonomi-akuntansi syariah di SMA sederajat sebagaimana pendapat yang disampaikan oleh Dr. Jasmaniar, SE. M.Ec. Dev dan Trisnawati pada saat FGD:

"Proses internalisasi nilai-nilai ekonomi syariah dalam aktivitas hidup akan lebih efektif bila diajarkan lebih dini sebelum masa kuliah. Ada transfer of value sesuai Al-quran dan sunnah dalam bermuamalah. Bekal untuk mendalami ekonomi syariah di perguruan Tinggi”. (Dr. Jasmaniar, SE. M.Ec. Dev, Ketua Asosiasi Guru Ekonomi Wilayah Gorontalo).

"Sangat setuju. Kurikulum ekonomi syariah dan akuntansi syariah di SMA sederajat harus diterapkan/diintegrasikan dalam pelajaran. Menanamkan karakter syariah, mengenal ilmu sosial, membumikan ajaran syariah dalam berbagai bidang usaha". (Trisnawati, Wakil Kepala Sekolah bidang Kesiswaan MAN Insan Cendekia Gorontalo)

Poin penting yang dapat dipetik dari kedua pernyataan adalah bahwa pengembangan kurikulum ekonomi-akuntansi syariah di SMA sederajat merupakan bagian dari aktivitas pembelajaran yang sebaiknya disampaikan lebih dini kepada siswa. Bila saat ini di Perguruan Tinggi (PT) telah menjadikan ekonomi-akuntansi syariah menjadi bagian dari mata kuliah, maka penyajian materi ekonomi-akuntansi syariah di SMA sudah selayaknya untuk diajarkan. Hal ini didasarkan pada pertimbangan bahwa tidak semua siswa SMA sederajat melanjutkan pendidikan ke PT. Bagi siswa yang tidak melanjutkan pendidikan di PT, pengetahuan dan pemahaman tentang ekonomi-akuntansi syariah yang telah diperoleh saat di SMA menjadi bagian penting untuk diimplementasikan dalam perannya sebagai pelaku bisnis di masyarakat. Bagi siswa yang melanjutkan pendidikan di PT, hal ini dapat menjagi dasar pengetahuan untuk lebih mendalami ekonomi-akuntansi syariah.

Penyampaikan materi ekonomi-akuntansi syariah bagi siswa SMA sederajat menjadi bagian dari proses membangun karakter siswa untuk bermuamalah secara syariah, sesuai dengan nilai-nilai yang disampaikan Al-quran dan hadis. Hal ini menjadi syiar penting agar kelak bila siswa menjadi pelaku bisnis dalam bidang apapun diharapkan dapat menerapkan nilai-nilai Islam dalam aktivitas bisnisnya. Hamalik (2009) menjelaskan bahwa pengembangan kurikulum sebaiknya menggunakan beberapa landasan diantaranya adalah landasan sosial budaya dan agama yang berlaku dalam masyarakat Indonesia (Kunandar, 2011).

Landasan sosial budaya dan agama merupakan asumsi-asumsi yang bersumber dari sosiologi dan antropologi yang dijadikan titik tolak dalam mengembangkan kurikulum. Karakteristik sosial budaya dan agama dimana peserta didik hidup berimplikasi pada program pendidikan yang akan dikembangkan. Kebudayaan bukan hanya berupa material belaka, melainkan juga berupa sikap mental, cara berpikir dan kebiasaan hidup.

Kebudayaan mencakup berbagai dimensi, diantaranya keluarga, pendidikan, politik, ekonomi, sosial, teknologi, dan rekreasi. Semua dimensi tersebut hendaknya dipertimbangkan dalam proses pengembangan kurikulum. Hussain et al., (2011) menjelaskan bahwa inti dari pencapaian tujuan kurikulum tergantung pada proses 
evaluasi selama pengembangan. Jika indikator proses melibatkan suatu proses yang komprehensif di tingkat akar rumput yang akan digunakan, maka akan ditemukan hal-hal mengenai pertimbangan obyektif dan pertimbangan organisasi selama proses pengembangan kurikulum.

Tabel 1: Konsep Mata Pelajaran Ekonomi-Akuntansi Syariah Dalam Kurikulum Muatan lokal di Madrasah Aliyah

\begin{tabular}{|c|c|c|c|c|}
\hline NO & $\begin{array}{l}\text { Kelas dan } \\
\text { Semester }\end{array}$ & $\begin{array}{c}\text { Kompetensi } \\
\text { Dasar }\end{array}$ & Materi & Dalil \\
\hline & $\begin{array}{l}\text { Kelas } 10 \text { Semester } \\
1\end{array}$ & 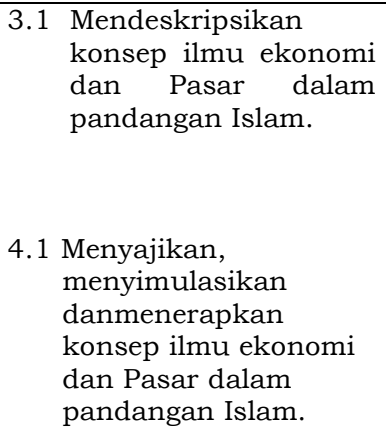 & 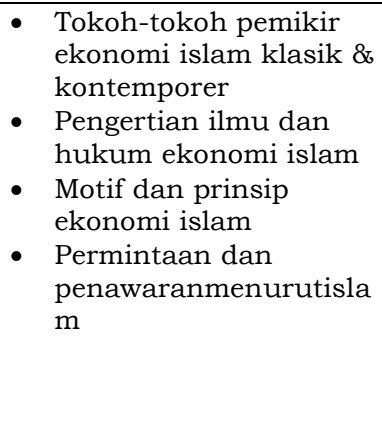 & $\begin{array}{l}\text { QS. Ibrahim 32- } \\
34 \\
\text { QS. Al-A'raf 31- } \\
32 \\
\text { QS. Al-Isra' 26- } \\
27 \\
\text { QS. Al Baqarah } \\
\text { 168 } \\
\text { QS. Al-Isra' 26- } \\
27 \\
\text { QS. Al-Baqrah : } \\
75 \\
\text { QS. luqman : } 20\end{array}$ \\
\hline
\end{tabular}

Kelas 10

Semester 2

Kelas 11 Semester

Kelas 11 Semester 2

Kelas 12 Semester
3.1 Mendeskripsikan peran kewirausahaan pendirian Baitul Maal Wat Tamwil (BMT)

4.1 Menanamkan jiwa kewirausahaan Syariah melalui pendirian BaitulMaal Wat Tamwil (BMT). Syariah melalui

- $\quad$ Produksi, konsumsi QS. Ibrahim 32-34 dan distribusi dalam QS. Al-A'raf 31-32 islam

- Harta dan kepemilikan

- Peran kewirausahaan

- Pengertian konsep Zakat, Infak dan Sedekah

4.1Menyajikan dan mengimplementasikan konsep Zakat, Infak dan Sedekah.
- Sistem ekonomi islam

- Fiqih muamalah dalam islam melalui pendirian Baitul Maal Wat Tamwil (BMT).

Kewirausahaan syariah

- Pentingnya

kewirausahaan syariah

- Konsep kewirausahaan syariah

- Pengertian Baitul Maal Wat Tamwil (BMT)

- Asas dan prinsip dasar BMT

- Pendirian dan permodalan BMT

- Kegiatan usaha BMT

- Kesehatan BMT

- Kendala pengembangan BMT

- Strategi pengembangan BMT

- Pengertian zakat, infak dan sedekah.

QS. Al-Isra' 26-27

QS. Al Baqarah 168 QS. Al-Isra' 26-27

QS. Al-Baqrah : 75

QS. Luqman : 20

QS. Al QS. Maidah: 8

QS. Al QS. Su'araa:

183

QS. Al QS. Zukhruf: 32

QS. A QS. Taubah:

60, 103

Qs. Al Maidah:2

QS. Al QS. Zukhruf: 32

QS. A QS. Taubah:

60, 103

Qs. Al Balat: 16

Qs. Al Maidah:2

- Manfaat Zakat, infak dan sedekah terhadap ekonomi suatuNegara

- Menghitung zakat maal dan zakat fitrah
QS. Al Baqarah:42, $84,110,177,277$
Qs. Al Balat: 16 
Kelas 12 Semester 2
3.2 Mendeskripsikan konsep Akuntansi syariah

4.2Menerapkan Akuntansi Syariah sesuai SAK Syariah
- Sejarah perkembangan akuntansi syariah

- Kerangka akuntansi syariah

- Pelaporan keuangan berdasarkan SAK syariah.
QS. Al QS. An-Nisa': 58 QS. Al QS. Al-Isra' 35 QS. Al QS. AlMuthaffifin: 1-6 QS. Al QS. AlMaidah: 4: QS. Al QS. AlBaqarah: 185

QS. An Nisa: 5

\subsection{Model Pengembangan Kurikulum Ekonomi Syariah dan Akuntansi Syariah untuk SMA Sederajat}

Model dapat juga disebut dengan pola, contoh, ataupun panduan dari sesuatu yang akan dihasilkan (Kurinasih \& Sani, 2014: 28). Jika dikaitkan dengan konsep kurikulum maka model kurikulum dapat diartikan sebagai suatu desain atau panduan dari suatu bentuk kurikulum yang akan menjadi acuan dalam pengembangan kurikulum berikutnya. Empat model kurikulum yang dikembangkan, yaitu pertama model adminsitratif, disebut sebagai model garis dan staf atau yang kurikulumnya dilakukan oleh kalangan atas atau praktisi pengembangan pendidikan kemudian dilaksanakan sepenuhnya oleh guru dan pihak sekolah dikatakan pula sebagai model dari atas ke bawah (top down approach). Kedua model grass-roots, model kebalikan dari model administratif. Inisiatif pengembangan kurikulum, bukan datang dari atas tetapi dari bawah, yaitu bersumber dari inisiatif guru atau komponen sekolah. Pengajar yang merupakan para pelaksana kurikulum di sekolah. Model ini didasarkan dari pendapat bahwa gurulah yang mengetahui kondisi lingkungan sekolah.

Konsep model pengembangan yakni melakukan kerja sama dengan kepala sekolah, pihak stakeholder, kemudian dikomplitkan dengan beberapa praktisi pendidikan mereka dalam mengembangkan kurikulum yang akan diimplementasikan. Model ini tidak mengubah kurikulum secara keseluruhan, namun hanya beberapa bagian atau aspek tertentu yang ada dalam kurikulum yang disesuaikan dengan kebutuhan dan hanya berlaku untuk bidang studi dan sekolahsekolah tertentu saja. Pengembangannya betul-betul berdasarkan sikap kritis guru yang menginginkan adanya perbaikan kurikulum berdasarkan temuan masalah di lapangan. Tentu hal ini dibutuhkan guru-guru yang memiliki pemikiran yang inovatif, kreatif dan profesional. Model pengembangan kurikulum menggabungkan kedua model pengembangan kurikulum sebelumnya disebut model sentral desentralisasi. Kerjasama antara pihak pejabat tinggi pendidikan dengan para guruguru di lapangan.

Ide bisa saja datang dari pusat namun tetaplah guru yang menjadi ujung tombak karena gurulah yang paling mengerti kebutuhan murid-murid di sekolah. Yunus \& Alam (2014: 2-3) menjelaskan bahwa dalam hal pengembangan kurikulum, ada tiga hal penting yang patut dipertimbangkan, yakni: 1) Obyek yang dikembangkan harus sesuai dengan berbagai program pendidikan yang berisi kegiatan pendidikan dan pengajaran kemudian harus dirancang dan diprogramkan secara sistematik sebagaimana peraturan yang berlaku di Indonesia. 2) Pihak-pihak yang ikut serta dalam mengembangkan kurikulum adalah orang-orang yang terkait dengan masalah kurikulum seperti berbagai ahli yang sesuai yang ada pada lembaga pendidikan. 3) Ada tiga pendekatan dalam perencanaan dan pengembangan kurikulum, yakni: Pendekatan berdasarkan materi, pendekatan berdasarkan tujuan, dan pendekatan berdasarkan kemampuan. 
Pengembangan kurikulum dibutuhkan suatu proses evaluasi yang pada nantinya akan berdampak pada hasil yang dicapai semakin baik dan mampu untuk dikembangkan. Hal tersebut diperkuat dengan pernyataan dari Üstünlüoğlu et al., (2012) bahwa untuk menguji kecocokan antara apa yang diinginkan untuk program dibandingkan dengan keadaan yang sebenarnya dari program, dengan kata lain bertujuan membuat penilaian tentang tingkat pelajar, keterampilan dan pengetahuan, dan membuat saran dalam rangka perbaikan kurikulum dan pengembangannya secara keseluruhan.

Tabel 2: Insert Ekonomi-Akuntansi Syariah Dalam Kurikulum Ekonomi-Akuntansi untuk SMA

\begin{tabular}{|c|c|c|c|}
\hline No. & $\begin{array}{l}\text { Kelas dan } \\
\text { Semester } \\
\end{array}$ & Standar Kompetensi & $\begin{array}{l}\text { Insert materi ekonomi } \\
\text { syariah }\end{array}$ \\
\hline \multirow[t]{7}{*}{1} & Kelas 10 sem 1 & Memahami Kebutuhan Manusia & $\begin{array}{l}\text { Keinginan dan kebutuh } \\
\text { dalam konsep ekonomi } \\
\text { syari'ah }\end{array}$ \\
\hline & & $\begin{array}{l}\text { Mendeskripsikan berbagai } \\
\text { sumberekonomi yang langka } \\
\text { dankebutuhan manusia yang } \\
\text { tidak terbatas }\end{array}$ & $\begin{array}{l}\text { Pengelolaan SDA dalam } \\
\text { ekonomi syari'ah }\end{array}$ \\
\hline & & $\begin{array}{l}\text { Mengidentifikasi masalah pkok } \\
\text { ekonomi tentang apa, } \\
\text { bagaimana, dan untuk siapa } \\
\text { barang diproduks }\end{array}$ & Etika produksi \\
\hline & & $\begin{array}{l}\text { Mengidentifikasi sistem ekonomi } \\
\text { untuk memecahkan masalah }\end{array}$ & Sistem ekonomi syari'al \\
\hline & & $\begin{array}{l}\text { Mendeskripsikan pola perilaku } \\
\text { konsumen dan produsen dalam } \\
\text { kegiatan ekonomi }\end{array}$ & $\begin{array}{l}\text { Etika produksi dan } \\
\text { konsumsi }\end{array}$ \\
\hline & & $\begin{array}{l}\text { Mengidentifikasi faktor-faktor } \\
\text { yang mempengaruhi permintaan } \\
\text { dan penawaran }\end{array}$ & $\begin{array}{l}\text { Teori permintaan dan } \\
\text { penawaran Islami }\end{array}$ \\
\hline & & $\begin{array}{l}\text { Mendeskripsikan pengertian } \\
\text { harga dan jumlah } \\
\text { keseimbangan }\end{array}$ & $\begin{array}{l}\text { Mekanisme penentuan } \\
\text { harga dalam ekonomi } \\
\text { syari'ah }\end{array}$ \\
\hline 2 & Kls 10 sem 2 & $\begin{array}{l}\text { Mendeskripsikan masalah- } \\
\text { masalah yang dihadapi } \\
\text { pemerintah di bidang ekonomi } \\
\text { 1. Menjelaskan unsur-unsur } \\
\text { manajemen } \\
\text { 2. Menjelaskan } \\
\text { manajemen fungsi } \\
\text { pengelolaan badan usaha } \\
\text { 3. } \begin{array}{l}\text { Mendeskripsikan peran } \\
\text { badan usaha dalam }\end{array} \\
\text { perekonomian Indonesia }\end{array}$ & $\begin{array}{l}\text { Kebijakan Pengentasan } \\
\text { Kemiskinan dalam } \\
\text { Ekonomi Syari'ah } \\
\text { Peran ESQ dalam } \\
\text { manajemen }\end{array}$ \\
\hline
\end{tabular}

Dali1

QS. Al-A'raf 31-32

QS. Al-Maidah 87-88

QS. QS. Alfurqon 67

QS. Ali Imron:14

QS. Luqman 20

QS. Ibrahim 32-34

QS. Hud 61

QS. Al-A'raf 56

QS. An Nahl:5, 11

QS. Al Maidah 33

QS. Ibrahim 32-34

QS. Hud 61

QS. Al-A'raf 56

QS. Al Maidah: 49,

QS. Al Isra: 47

QS. Al-Nisa' 29

QS. Al-Baqarah 128

Qs. Al-Maidah 8, 17

QS. Al Mulk:15;

QS. Ibrahim 32-34

QS. Al-A'raf 31-32

QS. Al-Isra' 26-27

QS. Al Baqarah 168

QS. Al-Isra' 26-27

QS. Al-Baqrah : 75

QS. Luqman : 20

QS. Al-Maidah: 8

QS. Al-Su'araa: 183

QS. Al-Jumu'ah 10 QS. Al-Taubah 60,

103

QS. Al-Dzariyat: 56

QS. Al-Anbiya': 107

QS. Al-Insyirah 7-8

QS. Al-Shaf 4

HR. Tabrani

:"Sesungguhnya

Allah sangat mencintai orang yang jika melakukan sesuatu pekerjaan , dilakukan secara itqan (tepat, tearah, jelas, tuntas)"

QS. Al-A'raf 31-32

QS. Al-Isra' 26-27

QS An-Nisa'9 
Mendeskripsikan kurva permintaan investasi Menjelaskan permintaan dan penawaran uang

1. Mendiskripsikan pengembangan

cara dan Koperasi Sekolah

2. Menghitung pembagian sisa hasil usaha

Menjelaskan permintaann dan penawaran uang

Kls 11 sem 1
1. Mengklasifikasi ketenagakerjaan

2. Mendeskripsikan pembangunan ekonomi

3. Mendeskripsikan proses pertumbuhan ekonomi

4. Mendeskripsikan pengangguran beserta dampaknya terhadap pembangunan nasional

1. Menjelaskan

pengertian,fungsi, tujuan APBN dan APBD

. Mengidentifikasi sumbersumber penerimaan pemerintah pusat dan pemerintah daerah

3. Mendeskripsi kan kebijakan pemerintah di bidang fiskal

4. Mengidentifikasi jenis-jenis pengeluaran pemerintah pusat dan pemerintah daerah Menjelaskan konsep PDB, PDRB, PNB, PN

Membedakan peran bank umum dan bank sentral
Teori uang dalam Ekonomi Syari'ah

Pengenalan Koperasi Syariah dan Baitul Mal wa Tamwil (BMT)

Kebijakan moneter dalam ekonomi syari'ah

Pembangunan ekonomi dalam perspektif ekonomi syari'ah

Kebijakan anggaran dan fiskal dalam ekonomi syari'ah

Pendapatan Nasional dalam Perspektif Ekonomi

Syari'ah

Perbankan syari'ah

1. Mengenal jenis dalam bursa efek

produk

Mendeskripsikan

bentuk pasar barang

3. Mendeskripsikan mekanisme kerja bursa efek
QS Al furqon 67

QS Attaubah 34

QS. Yusuf 20

HR. Muslim : "Dinar

dengan dinar,

tidakadakelebihanant

arakeduanya, dan

dirham dengan

dirham,

tidakadakelebihanant

arakeduanya

(jikadipertukarkan)"

QS. Al-Maidah: 2

QS. Al-Zukhruf: 32

QS. At Taubah: 60

103

Qs. Al Balat: 16

QS. Al-Baqarah 188

QS. Al-Nisa' 58

QS. Al- Jumu'ah 10

QS. Al-Qasas 77

HR. Buhkhori

:"Tidakadamakanan yang

lebihbaikdaripadama

kanan yang

dihasilkanolehtangan sendiri".

QS. Al-Baqarah: 43

QS. Al-Taubah: 60,

103

QS. AL Aadiyaat: 8

QS. Al-Hasyr 7

QS. Al-Taubah 60,

103

QS. Al-Baqarah: 233

275-279, 280,282,

283

QS. Ali Imran: 130

QS. Al-Nisa': 29, 160-

161

QS. Al-Rum: 39

QS.Al An'am:152,

QS. Al Israa':35

QS.Asy Syuura:32

OS. Al-Maidah 1

QS. Al-Baqarah 275

HR. Turmudzi :

"KaumMusliminterika tdengansyarat-syarat yang merekabuat, kecualisyaratmengha ramkan yang halal danmenghalalkan yang haram"

QS.Al-Maidah:2

QS.Al-Hujurat: 13

QS.Al-A'raf: 158
Kerjasama di bidang faktor pendorong perdagangan internasional

2. Mengidentifikasi kurs tukar valuta asing, dan neraca pembayaran 


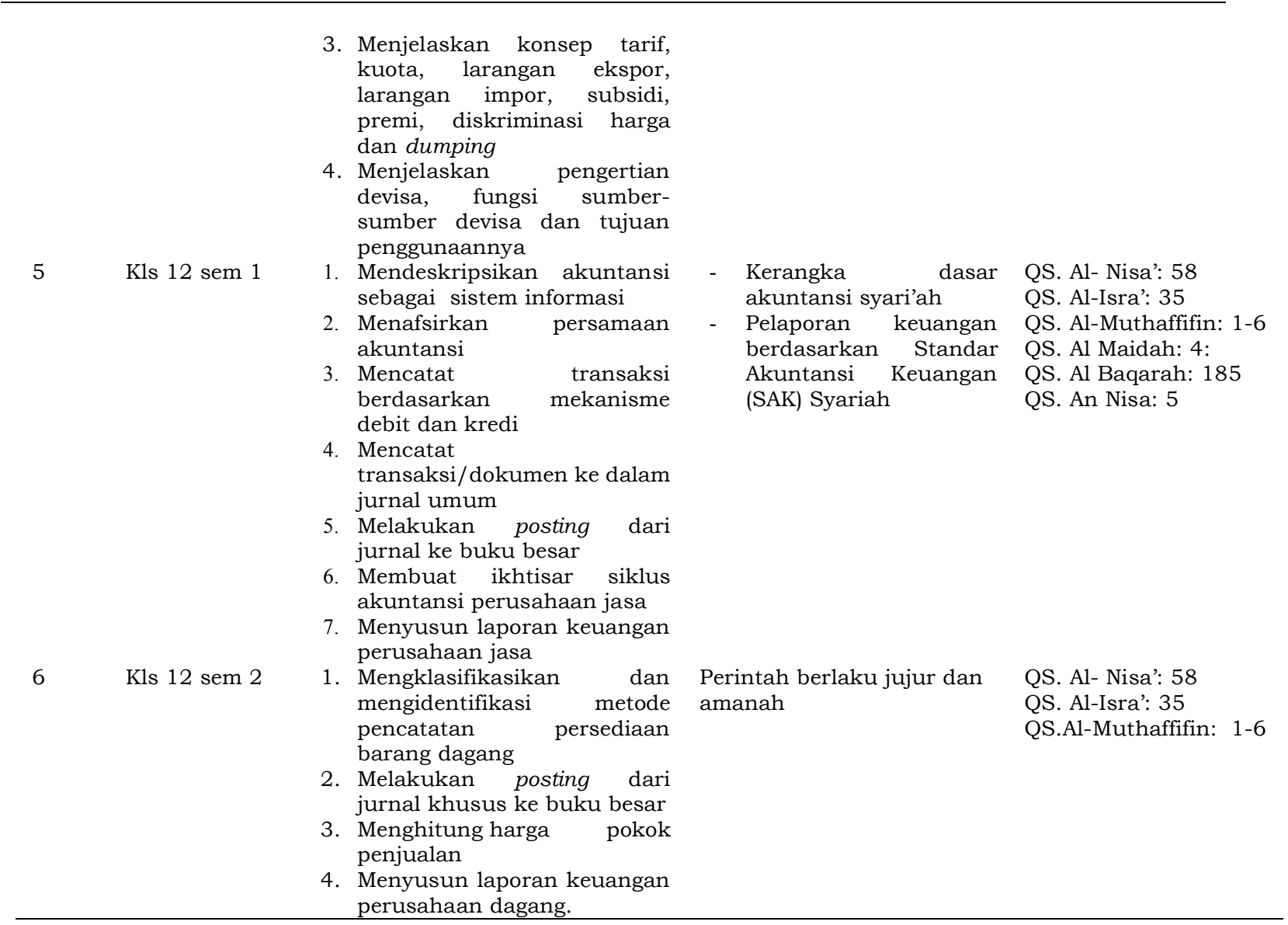

\subsection{Model Monolitik dan Model Integratif sebagai Bentuk Pengembangan Kurikulum}

Model monolitik dapat dilakukan melalui pembukaan jurusan atau keahlian perbankan syariah untuk sekolah menengah kejuruan (SMK) atau melalui penetapan mata ekonomi syariah dan akuntansi syariah sebagai mata pelajaran. Model monolitik untuk di SMK telah diatur dalam Permendikbud No. 70 Tahun 2013 tentang Kerangka Dasar dan Struktur Kurikulum. Berdasarkan aturan ini, lembaga pendidikan, khususnya bagi SMK dapat membuka paket keahlian "Perbankan Syariah" dan khususnya pada program studi keahlian akuntansi, terdapat enam mata pelajaran yang menjadi tambahan peminatan perbankan syariah, yaitu Pengelolaan Kas, Produk Syariah, Ekonomi Islam, Akuntansi Perbankan Syariah, Komputer Akuntansi Perbankan Syariah, Administrasi Perpajakan. Khusus untuk mata pelajaran ekonomi syariah dan akuntansi bank syariah.

Model monolitik berikutnya adalah menjadikan ekonomi-akuntansi syariah menjadi mata pelajaran peminatan dan muatan lokal di Madrasah Aliyah. Hal ini ditemukan berdasarkan hasil observasi kurikulum di kedua Madrasah Aliyah di Gorontalo. Ekonomi syariah menjadi mata pelajaran peminatan telah diterapkan oleh Madrasah Aliyah Negeri (MAN) Insan Cendekia Gorontalo. Sedangkan konsep mata pelajaran ekonomi syariah menjadi mata pelajaran muatan lokal sebagaimana ditawarkan oleh Aldiwanto Landali sebagai guru ekonomi dan akuntansi di MAN 1 Pohuwato. Tabel 1 menampilkan konsep kurikulum ekonomi-akuntansi syariah dalam kurikulum muatan lokal.

Model integratif melalui insert materi ekonomi dan akuntansi syariah yang relevan pada mata pelajaran ekonomi dan akuntansi atau melalui program literasi terintegrasi dengan kegiatan ekstrakurikuler untuk di SMA (lihat Tabel 2). Model 
integratif merupakan hasil penyesuaian Kurikulum 2013, revisi 2018 berdasarkan konsep yang disampaikan oleh Khairul Anam (Dosen Universitas Negeri Surabaya sebagai Tim Pakar). Model pengembangan kurikulum ekonomi-akuntansi di SMA sederajat dapat dibangun dari konsep yang ditawarkan dari guru mata pelajaran berdasarkan lingkungannya (model Grass-Roots). Model ini sangat fleksibel dan untuk mengimplementasikan ke ranah sekolah yang lebih kuat membutuhkan dukungan dari pengambil kebijakan (stakeholders) Pengembangan model kurikulum ekonomi dan akuntansi syariah di level SMA sederajat bermaksud untuk menanamkan etika dalam berekonomi, berbisnis, dan berakuntansi pada peserta didik, keluarga, dan masyarakat dan memberikan wawasan mengenai transaksi bisnis, ekonomi, dan akuntansi syari'ah kepada anak didik pada khususnya dan masyarakat umumnya.

\section{SIMPULAN}

Penelitian ini telah menemukan dua model pengembangan kurikulum ekonomi syariah dan akuntansi syariah yang dapat diterapkan pada jenjang SMA sederajat, yaitu model monolitik dan model terintegrasi. Model monolitik yang dapat diterapkan pada SMK dengan membuka paket keahlian perbankan syariah dan MA, sedangkan model terintegrasi yang dapat diterapkan di SMA. Penelitian ini menjadi acuan dalam rangka perencanaan yang dilakukan oleh peneliti berikutnya dalam menerapkan model pengembangan kurikulum ekonomi-akuntansi dijenjang pendidikan SMA sederajat.

\section{REFERENSI}

Alotaibi, Abdullah, K., \& Lone, F. A. (2016). Islamic Banking and Finance Education: A Comparative Study of Saudi Arabia and The UK. International Journal of Economic Research, 13(7), pp 2651-2662.

Hamalik, O. (2009). Dasar-dasar pengembangan Kurikulum. PT Remaja Rosdakarya. Hussain, A., Dogar, A. H., Azeem, M., \& Shakoor, A. (2011). Evaluation of Curriculum Development Process. InternationalJournal of Humanities and Social Science, $1(14)$.

Kamayanti, A., \& Lutfillah, N. (2021). Kurikulum dan pembelajaran berbasis kesejahteraan semesta. Jurnal Ekonomi, Manajemen, Dan Akuntansi Islam, 93103.

Kunandar. (2011). Implementasi Kurikulum Tingkat Satuan Pendidikan (KTSP) dan Sukses Dalam Sertifikasi Guru. PT. Raja Grafindo Persada.

Kurinasih, I., \& Sani, B. (2014). Implementasi Kurikulum 2013 (Konsep dan Penerapan). Penerbit Kata Pena.

Niswatin, Laliyo, L. A. ., \& Rasuli, L. O. (2017a). Factors Influencing The Development Of The Economic, Business and Islamic Accounting In Indonesia. Dipresentasekan 2nd International Conference on Economics,Education, Business, and Accounting Di Makassar 28 - 29 Oktober.

Niswatin, Laliyo, L. A. ., \& Rasuli, L. O. (2017b). Potential Resources Based On Economic Education Business and IslamicAccounting In Gorontalo, Indonesia. International Journal of Business and Management Invention (IJBMI), 1(10).

Niswatin, Rasuli, L. O., \& Monoarfa, R. (2016). Development Strategy of Islamic Economic, Business, and Accounting In Gorontalo, Indonesia. International Journal of Economic Research, 13(7), 3083-3096.

Triyuwono, I. (2015). Filosofi tauhid: Mendekonstruksi Pendidikan Akuntansi Syariah yang Sekuler. Makalah Dipresentasekan Pada Workshop Nasional Kurikulum Akuntansi Syariah Di UIN Sunan Kalijaga Tanggal 6 Mei 2015. 
Üstünlüoğlu, E., Zazaoğlu, K. F. A., Keskin, M. N., Sarayköylü, B., \& Gülfem Akdoğan. (2012). Developing A Cef Based Curriculum: A Case Study. International Journal of Instruction E-ISSN: 1308-1470, 5(1).

Yunus, H. (2011). Pengaruh Metode Pembelajarandan Gaya Kognitif Terhadap Hasil Belajar Mahasiswa. Universitas Negeri Gorontalo.

Yunus, H., \& Alam, H. V. (2014). Perencanaan Pembelajaran Berbasis Kurikulum 2013. Penerbit Deepublish. 
Halaman ini sengaja dikosongkan 